OPEN ACCESS

UNIVERSITY OF THE

WEST of SCOTLAND

UWS Academic Portal

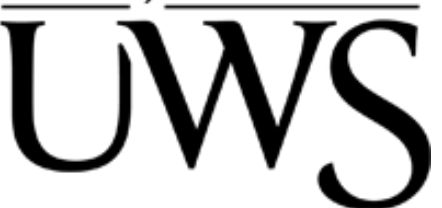

\title{
Documenting entrepreneurial opportunism in action
}

Smith, Robert

Published in:

British Food Journal

DOI:

10.1108/BFJ-07-2016-0324

Published: 01/01/2017

Document Version

Peer reviewed version

Link to publication on the UWS Academic Portal

Citation for published version (APA):

Smith, R. (2017). Documenting entrepreneurial opportunism in action: A case study of sheep theft in the UK from a food supply chain perspective. British Food Journal, 119(1), 105-121. https://doi.org/10.1108/BFJ-07-20160324

\section{General rights}

Copyright and moral rights for the publications made accessible in the UWS Academic Portal are retained by the authors and/or other copyright owners and it is a condition of accessing publications that users recognise and abide by the legal requirements associated with these rights.

Take down policy

If you believe that this document breaches copyright please contact pure@uws.ac.uk providing details, and we will remove access to the work immediately and investigate your claim. 


\title{
Documenting entrepreneurial opportunism in action: A case study of sheep theft in the UK from a food supply chain perspective.
}

Robert Smith, Professor of Enterprise and Innovation, University of the West of Scotland, Dumfries. Rob.Smith@uws.ac.uk

\begin{abstract}
Purpose: The contemporary rustler is a shrewd businessman, or rogue farmer exploiting food supply chain anomalies. Indeed, the first conviction in the UK for 20 years was a farmer stealing from neighbouring farmers. The theft of sheep in the UK is an expanding criminal enterprise which remains under researched. This study examines what is known of the illegal trade and its links to food fraud from a supply chain perspective with an emphasis on food integrity issues.
\end{abstract}

Design/methodology/approach: There is a dearth of current viable literature on livestock theft in a Western context making it necessary to turn to socio-historical research and to official documents such as those published by the NFU and other insurance companies to build up a picture of this illegal practice. This is supplemented by documentary research of articles published in the UK press.

Findings: From this raw data a typology of rustlers is developed. The findings point to insider 'supply chain' knowledge being a key facet in the theft of livestock. Other examples in the typology relate to urban thieves wrestling live sheep into a car and to industry insiders associated with the abattoir sector.

Limitations: The obvious limitations is that as yet there are few detected cases of rustling in the UK so the developing typology of rustlers is sketchy. Another limitation is that much of the evidence upon which the typology is developed is anecdotal.

Originality/Value: The typology should prove helpful to academics, insurance companies, investigators, industry insiders and farmers to help them understand this contemporary crime and how to prevent its spread. It also sheds light on food integrity in relation to the purchase and consumption of the end product in that customers expect to be purchasing legally and ethically reared animal products.

Keywords: Rustler; Livestock Theft; Supply Chain Theory; Criminal Entrepreneurship; Routine Activities Theory; Opportunity Theory. 


\section{Introduction}

Food integrity, its traceability, safety, quality and authenticity is a contemporay normative issue to food scientists, the food industry and to consumers (Hoorfar et al, 2011; Manning \& Soon, 2014; and Manning \& Smith, 2015). Integrity at its most basic level relates to the core concepts of being honest, having strong moral principles and being transparent in one's dealings. Indeed, integrity is an everyday phenomenon and extends to the concepts of 'Ethics' as well as 'Personal' and 'Professional Integrity' (Pritchard, 2006) and this imposes a responsibility on both the food professional and anyone in their supply chain to be truthful and open. Of particular interest is the concept of 'People Integrity' in the food-supply chain industry (Manning, 2016: Forthcoming). However, integrity is also a valuable commodity in business (Sagoff, 1995) which must be earned and safeguarded. In the literature the talk is of monitoring and detecting, predicting and reacting and scientific techniques are the main topic of conversation. However, possibility of theft and of stolen meat being channelled into the food supply chain is seldom considered albeit consideration has been given to developing an organizational typology of criminals in the meat supply chain (Manning, Smith \& Soon, 2016). The Elliott Review (2014) into the integrity and assurance of food supply networks published in the aftermath of the 2013 horsemeat scandal criticised the way food is sourced, procured and distributed dishonestly (also see Agnoli et al, 2016 in this journal). The report highlighted obvious legal, moral and ethical dimensions at play in the food supply chain. This article addresses issues of food supply chain integrity, food crime and food fraud as well as providing fresh insights into the culture, integrity and ethics of those who operate in the food supply chain. Shears, (2010) argued in this journal that to combat food fraud lessons must be learned from history. This article takes up this challenge. 
Once considered as being a traditional folk crime, rustling is a topical, pernicious, contemporary crime (Lektzian \& Perez, 2008) and encompasses all forms of livestock theft per-se. However, here we are concerned only with sheep theft and related supply chain issues. Livestock theft is defined as a property crime of economical nature (Clack, 2014). Much rural, or farm crime, is committed by predatory urban marauders and organized crime groups (See Smith, 2004, Smith, 2009 and Smith \& McElwee, 2015) but this is only one possible category. Indeed, the dominant contemporary perception of the rural criminal is that of the urban based maurader, raiding and plundering the countryside from deprived housing estates (Smith, 2010; Jones, 2012). Yet when we consider the very notion of 'Rustling' and the 'Rustler' as a genre, we invoke idyllic and romanticised images of rural banditry (see for instance Hobbsbawm, 2000). ${ }^{1}$ This romanticised, 'Picarian' imagery induces socially approved images of the outlaw which somehow excuses the crime and the criminal but it does not fit the contemporary scenario. This theme is articulated in the words of one security consultant who recently blogged "...the days of stealing a few sheep in the middle of the night from rural fields are long gone as organised rustlers simply take the whole flock and proceed to butcher it in unlicensed slaughter houses and then distribute it all within 24 hours". ${ }^{2}$ Thus the contemporary rustler is no champion of social justice, but a criminal predator operating from within the farming community to exploit the food supply chain ${ }^{3}$. This is both contentious and problematic because it shatters the socially constructed imagery of the atavistic, almost picaresque (McKenzie, 2004) crime traditionally blamed on outsiders. Current knowledge suggests insider dealing in the farming and food industries. Such sharp practices normally unveiled in the press have a toxic effect on trust among rural communities and the supply chain. Nevertheless, the wholesale theft of sheep causes financial and emotional distress and ruins years of hard work. The related issues of trust and integrity are under researched in supply chain literature. 
Despite the upsurge of livestock theft and in particular sheep rustling in the UK and Ireland in recent years we know very little about the perpetrators and their role in the criminal food supply chain. Consequentially, this article makes a start to the profiling process by developing a working typology of criminals involved in the illegal supply chain - based on documentary evidence (Scott, 2014) available in the public domain. It is a rudimentary profile at best. This topical case treats the theft of sheep as a business orientated practice from a supply chain perspective linked to entrepreneurial opportunism. It is in this context that it must be understood.

We begin with a review of the documentary evidence upon which such stereotypes are based. We then consider the criminological perspective before first considering the sociohistorical approach and then routine activities and opportunity thesis and finally supply chain issues. From the historiographic reading we develop a protean typology of rustlers. From there we discuss methodology, and method, in relation to conducting documentary research before presenting ten case stories gleaned from media sources. A new, contemporary typology emerges which is influenced by the past via a merger of historical and contemporary typologies forming a new model which impacts on the food supply chain.

\section{Reviewing and documenting the available evidence / data}

The academic literature on rustling, livestock and sheep theft is sparse and as yet not deeply empirical. ${ }^{4}$ Indeed, it is based primarily on documentary research (Scott, 2006: 2014) from newspaper and official documentary sources (e.g. NFU Bulletins). We examine the criminological perspective and socio-historical perspectives before reviewing contemporary documentary evidence. We then consider how an understanding of routine and opportunity theories influence our understanding of rustling as a commercial, quasi-entrepreneurial venture. 


\section{Considering the Criminological perspective:}

There are a small number of academic, criminological articles on livestock theft spread across a diversity of journals in farming and rural studies. Some are articulated in American or Australian settings (Donnermeyer \& Barclay, 2005). In a UK/ Western context, there are a few criminological articles which touch on sheep and livestock theft, but do specifically relate to the crime (see for example, Smith, 2004; Jones, 2010; Jones, 2012; Smith \& McElwee, 2013). These articles relate primarily to farm crime in a wider sense focusing on the activity of theft as the topic of interest and not wider supply chain issues. From a criminological and indeed investigative perspective this focus on theft skews the raw data because investigators and journalists alike concern themselves with only a small part of the wider supply chain. The consequences of this imbalance are that, as mentioned above, academics have to rely heavily on either historical studies, or on journalistic or official documentary sources, first documenting and then creating their own conceptual and theoretical models. The sociohistorical perspective proved useful.

\section{Considering the Socio-historical perspective:}

Much of our sketchy knowledge on sheep rustling is derived from a socio-historical perspective based on custom and socialisation which has to be taken into consideration (see for example Wells, 1984; Shakesheff, 2003; Howard, 2004; and Woodward, 2008). Wells (2003) positions sheep rustling within the social contexts of the industrial and agricultural revolutions and the growth of towns and cities occupied by a former rural dwelling population with a knowledge of rural ways. The main thrust of the argument relates to changing occupational 
practices and habits. Shakesheff (2003) in studying social and petty crime in the context of protest, highlighted the existence of sheep rustling gangs in rural Hertfordshire. Similarly, Howard (2004) examined pre-trial court documents from early modern Wales / Denbighshire to investigate attitudes and responses to such theft. He looked beyond the ideals of vigilance and communal responsibility finding that such thefts did not occur in isolation but were part of a course of community action with a variety of outcomes - non-action; investigation and prosecution; and alternative resolutions that bypassed the courts. Indeed, Howard uncovered an everyday 'world of stolen goods' and its social and economic rewards in local networks of reciprocal favours, gifts and alliances.

Using a similar approach, Woodward (2008) highlighted the seasonality of much agricultural crime and articulates that in many rural communities, sheep rustling was a morally justifiable act of survival, expected of men for the communal good. It was a form of rural roguery (ala Tonnies, 1926). According to Woodward there were three main seasons which saw an increase in sheep theft - namely winter, early-summer and mid-autumn. Thefts often depended on opportunities to market the stolen sheep and upon intensity of shepherding. The argument being that in the spring, and early summer sheep were protected by shepherds because of the need for a continual presence. However, at other times, the farmers were more occupied / preoccupied by other farming rituals and chores increasing opportunities for larceny.

Woodward adopted a routine activities approach (Cohen \& Felson, 1979) which is dependent upon the nature of conditioning relating to everyday life. Routine activities theory takes the focus of analysis away from the criminal per se to consider routines surrounding the victim and their stewardship of their possessions. Routine crime patterns occur where there is a coming together of various circumstances and influences. For sheep theft to occur there must be an opportunity condition in that there must be a suitable available target; a suitably 
motivated offender; and finally the likelihood of a theft occurring is dependent upon a final condition - whether it is protected or not.. There are several sets of circumstances which predicate sheep theft namely - the buoyancy of sheep sales, the condition of the sheep, and the intensity of shepherding. Woodward was concerned with the characteristics and motives of the thieves and argues that one must examine the characteristics of the suspects and their possible motives because they have important implications which influence the seasonal patterns of theft. The issue of motivation was explored in depth by both Rule (1982) and Wells (1984) on whom Woodward drew. Woodward, drew inferences from the age and occupation of the thieves, their strategies; the number of sheep stolen; and whether there was evidence of gang activity, recidivism and professionalism. He identified a typology of sheep thieves ranging from amateurs to acquisitive thieves. The suspects were divided, by occupational status into three groups:-

- The first being those 'Of the land' and consisted of occupations such as Farmers. Yeoman, Waggoners, Husbandmen, and Shepherds. Many including farmers were described as propertied criminals. Woodward argued that the existence of this landed group should not be a source of surprise because small farms occupied a particularly prominent role in Welsh agriculture. Court records demonstrate that these 'yeoman farmers' often supplemented their incomes through labouring, shepherding and other work and occasionally through sheep-theft. Woodward stressed that a considerable proportion of stolen sheep were sold, or incorporated into other flocks, possibly to be sold later.

- The second group are Labourers (both urban and rural). Many had experience of farms and thus a knowledge and opportunity. This group included amateurs and the more organized as well as husband and wife teams who stole to stave off hunger. 
- The third group consisted of artisans and tradesmen and a large number of these were butchers. This is hardly surprising because butchers have both motive and opportunity.

These categories have utility even in the present day because stealing livestock is an activity that requires detailed insider knowledge of specialist markets.

\section{Considering the Socio-Contemporary perspective:}

During the early 2000s, livestock rustling was at a historically very low level. ${ }^{5}$ Consequentially, the attitude of the authorities was ambivalent to sheep theft. Under the terms of the 1968 Theft Act, stolen animals were once logged simply as missing property, meaning that there are no accurate figures on the actual number of crimes. Between 2010 and 2011, insurance claims by farmers for stolen livestock rose 170 per cent, according to NFU Mutual, which provides cover for three quarters of UK farmers. In 2012, numbers rose again and it is estimated that 69,000 animals were stolen at a cost to farmers of about $£ 6 \mathrm{~m}$. Unlike other common theft items, particularly electronic goods whose criminal resale price has collapsed in recent years, illegal meat sold into the legitimate food chain now commands nearly $£ 8$ a kilo compared with $£ 6.77$ in 2009 . Fattened lambs can fetch between $£ 200$ and $£ 300$ at market making it a lucrative opportunity.

For years, wild stories have circulated of organised foreign gangs rounding up sheep from fields, butchering them and selling the meat to city curry houses. There is talk of underworld gangs targeting UK farms. ${ }^{6}$ The evidence - such as it exists - reveals a more prosaic, if equally unsettling, picture. ${ }^{7}$ This evidence points to the involvement of farmers albeit the image of brutal modern gangs persists. One farming blogger talks of “....the modern livestock thief being a ruthless and often violent criminal. He is usually part of an organised gang that will use 
dogs, bolt cutters and even guns. There's an alarming rise in the use of firearms by modern sheep rustlers and their behaviour is callous. One farmer in the Midlands was devastated to discover that his whole flock had been shot in the neck during the night. The criminals then hauled the best carcasses into a van leaving the remaining sheep dead or dying in the field, covered in blood". The blogger continues - ".... the practice of rustling has become big business due to the recent rise in meat and livestock prices. The average sale price of sheep has more than doubled over the past three years and minced lamb has gone up by almost 30 percent over the same period". The blogger blamed economic hardship thesis for the resurgence in rustling.

From the press articles, a profile of the contemporary rustler emerges from the pages of an organized crime gang with up to five participants. The gang will have Lorries, Quad bikes, and well-trained sheep dogs. They rapidly transport their quarry to slaughter or to be fattened well away from the scene of the crime and will have planned a fast route out of the county. There is also talk of men selling cheap meat round pubs and from vans. However, privately police sources argue that most of the rustling is being done by other farmers, or farm workers, rather than organised criminal gangs from the cities. The evidence as printed in the media points to the farming community offending against their peers whilst engaging in supply chain activities. ${ }^{8}$

\section{Understanding Supply Chain Issues:}

To better understand food supply chains and industry players it is necessary to break them down into their functional components and processes in the marketplace (Scott et al, 2011) hence the utility of developing a working typology such as this developed herein. Freeman 
(1999) placed crime in a market setting by considering it as a major economic activity which effects the incentives on both legitimate and criminal behaviours. Business decisions interact in a market setting making illegal supply chain practices an alternative strategy to raise income providing deniability or anonymity can be maintained. In the legal model pertaining to the sheep meat trade, the farmer breeds the sheep and after bearing the production expenses after lambing fattens up the sheep for sale to marts, abattoir owners, butchers or meat trading companies. There is also the Halal trade as a potential avenue for sale (Smith, 2004). The farmer generally makes a small profit dependent upon sheep prices. See figure 1 below for a representation of the supply chain.

\section{Insert figure 1 here.}

In most years the market is stable and profit can be predicted. However if there are problems with the market leading to depressed prices or unforeseen problems such as in the foot and mouth crisis then the market can collapse with disastrous results for farmers and producers. The current spike in livestock theft can be traced back to the Foot and Mouth in circa 2000 when the market collapsed. It was around this time that unscrupulous traders began to supply meat to the halal supply chain leading to collusion between traders and desperate farmers to recover financial losses. The problem for the industry is that once such connections and networks are established then an alternative black market is created which creates criminal capital (Platt, 2015).

\section{Insert figure 2 here.}

This model has various possible permutations and scenarios if the thieves are in collusion with the farmers and the abattoir owners, or selling direct to butchers. It must be stressed that there are no obvious connections between the thieves and the farmers, the abattoir owners, the distributers and the customers and that each individual case will have its unique points of connectivity. Obviously the more cut outs / disconnects there are in the chain the higher the 
profits for the thieves who do not have the production costs to bear. In terms of production costs, the thieves only have labour and transportation costs to bear. It must be borne in mind that these costs are not at the same level as the legitimate production costs faced by honest producers such as inspection costs, testing costs, and meeting temperature control requirements. However, in the food supply chain trust and integrity are generally taken on face value and there is no known scientific test to establish if meat is stolen. Granted labelling can vouch for the provenance of where a product was grown or reared but not for the actual contents inside the package.

\section{Introducing routine and opportunity theories:}

Of obvious importance is the concept of routine activities theory (Cohen \& Felson, 1979) which situates the importance of routine, ritual and everyday activities within criminal and entrepreneurial behaviour. This theory suggests that the modus operandi of criminals and entrepreneurs is operationalised through ordinary every day actions and activities. Thus far from being aberrant mystical processes crime and entrepreneurship are best explained as being facilitated through normal, learned behavioural sets. Thus criminal often steal and entrepreneurs often do deals simply because they are good at it and it what they do best. If an opportunity presents itself a thief will steal, and an entrepreneur will exploit an opportunity to make money or close a deal. This makes 'Opportunity theory' (Mears, Scott, \& Bhati, 2007) a useful explanatory framework for helping to explain livestock theft. In particular, it is helpful in explaining guardianship measures.

Understanding opportunity recognition in relation to the individual entrepreneur is important. These are complex social dynamics. Entrepreneurial opportunity identification (Alvarez, 2010) and development utilises (Dubin's, 1978) theory building framework to 
theorise the opportunity identification process. This takes cognisance of entrepreneur's personality traits, social networks, and prior knowledge as antecedents of entrepreneurial alertness to business opportunities. Entrepreneurial "alertness" (Kirzner, 1985) is a necessary condition for the success of the opportunity identification triad: recognition, development, and evaluation (Ardichvili , Cardoza, \& Ray 2003). Entrepreneurial opportunities are objective in nature, but their recognition and exploitation by individuals is a subjective process (Shane \& Venkatamaran, 2000). For entrepreneurship to take place, an opportunity must be discovered and exploited and in the case of sheep theft it stands to reason that a farmer or someone connected to the industry is more likely to spot and exploit an entrepreneurial opportunity. An urban outsider would be unlikely to possess the innate knowledge of farming and livestock let alone the skills required to operationalise such a theft. Prior information, gained through industry experience or education, is usually necessary to identify a particular opportunity (Shane \& Venkatamaran, 2000). This prior information can only come from experience or knowledge of wider supply-chain participation.

To recapthere is a mismatch between popular media perceptions of who is involved in the theft of sheep and livestock in the UK and with the reality of the situation because specialised supply chain knowledge is required. At present there is no reliable system of establishing if food products have been legitimately produced albeit provenance or via Fair Trade membership are established ways of gaining consumer trust.

\section{On methodology and Method}


As there is/was no current viable academic literature on livestock theft in a Western context and because like the rural historians discussed above who used historiographic methods it was necessary to turn to official documents such as those published by the NFU and other insurance companies to build up a picture of the contemporary illegal practice it was necessary to engage in such practices too. Documentary research (Scott, 2014) was obviously a key methodological driver in this study. ${ }^{1}$ However, examining documents can only take you so far. A limitation of the methodology in relation to a contemporary crime such as rustling is that much of the reporting is based on reports of livestock theft which are undetected and merely report on the actual details of the theft and often report on speculation and not fact. This documentary research approach of articles published in the UK press, did however, permit the author to draw from such raw data to develop a typology of Rustlers. In the logistics literature, research results are usually produced almost entirely within a positivistic paradigm as are research questions (Gammelgaard, 2004). Little consideration is given to qualitative approaches based on analysing the actions of actors in the chain (Arbnor \& Bjerke, 1997). Consequently, the author made a trawl of the internet for articles related to sheep theft in the UK press and located over 500. Most articles reported on the theft of the sheep and made an appeal for witnesses. Much of the information on the potential perpetrators was speculative and often alarmist in nature and farmers were invariably presented as passive victims. These articles were discounted and through a constant iterative process were whittled down to those who provided specific details of the thieves. These article formed the basis of the cases below.

\section{Documenting the Results}

From the internet the following cases were located and written up as micro case stories:- 
Case Study 19: This case relates to DNA testing being used to secure what was then the first conviction for rustling in 25 years in 2012. A Durham farmer pled guilty to stealing 55 pregnant ewes worth $£ 15,000$, and his shepherd, was also found guilty of handling stolen goods. The sheep were found on a farm in Durham but were traced back to their original farm in Lancashire. The raid had occurred during the middle of the night and the crime was detected when another farmer became suspicious and alerted the police. The accused farmer is said to have held a grudge against the owner of the sheep. He was sentenced to nine months imprisonment, suspended for a year, while the shepherd admitted handling stolen goods and was ordered to serve a 12-month community order. The judge said the convictions dispelled the suggestion that such rural crime was carried out by "city folk". "In this case," he said, "the culprits were part of that very community and it is no surprise to hear that both of you have suffered with rejections by members of that same community - you wouldn't expect anything else."

Case Study $2^{10}$ : Reports on Cumbrian farmer who was unanimously found guilty by a jury on charges of sheep theft and intimidation, following a trial at Carlisle Crown Court. The farmer from Longtown, had stolen sheep belonging to another farmer. The sheep were worth $£ 6,273$. The accused farmer had tried to sell the sheep at six auctions across north Cumbria but ear tags attached to the livestock had linked them back to the owner. This case is important because it highlights that it was not committed by predatory urban based criminals but within the farming community itself.

Case Study $3^{11}$ : Relates to a Ribble Valley farmer /manager who was convicted of sheep theft. He stole sheep worth almost $£ 6,000$ from a Peak District farm and was jailed for 18 weeks. He 
denied the crime but was found guilty at trail at High Peak Magistrates' Court. He had bought the sheep using a cheque which failed to clear using a false name. He was named by other farmers who suspected him. Some of the stolen sheep were found at his farm. His vehicle and mobile phone were also recorded in Derbyshire on the day of the offence. Again this is an important case because it highlights the insider nature of the crime.

Case Study 412: This unusual case relates to a case of sheep stealing where the accused a farmer being sensationally dropped (after being called for four times) due to a lack of evidence. The sheep had false ear tags or had tags which had been tampered with. The sheep had been identified by their owners but the case dropped. This is an important case because it highlights the difficulty in bringing cases to court for a prosecution to occur.

Case Study 5 5 $^{13}$ : Relates to a prominent Dales farmer / pensioner who appeared before magistrates in Harrogate charged with stealing 10 mule ewes in October last year, 2013. The case centrered around an elaborate scheme of stealing the sheep from one farmer, hiding them in a second farmer's fields, in order to give them to a third. The accused farmer denied the conspiracy claiming he was merely looking after lost sheep. However, evidence was led that he had cut off their ID tags. He was cleared of stealing sheep by magistrates in Harrogate, but convicted of unlawfully removing the identifying tags. He was fined a total of $£ 635$. Again this highlights that it is crime committed by industry insiders.

Case Study 6 ${ }^{14}$ : This case relates to five members of a farming family being arrested and charged and who appeared at Durham Crown Court accused of making gain from allegedly 
stolen sheep. The family were all charged under the money laundering section of the Proceeds of Crime Act 2002. They had been found in possession of up to 115 sheep said to have been stolen from 14 farms in County Durham, North Yorkshire and Cumbria between 2010 and 2013. The case made history in that the police held a sheep identity parade for farmers to identify their property. The accused also benefited from breeding, lambing and from the EU's main subsidy to farmers, the single payment scheme, by bolstering their inventory of stock in records taken from the Government's agriculture department, Defra. This again highlights insider knowledge and illustrates that the thefts were carried out to improve the fecundity of the herd to meet future supply chain commitments without having to finance the activities through normal channels.

Case Study 715: This case relates to police in Northamptonshire stopping a vehicle on a routine patrol and finding two sheep hidden in the back of a van along with four "muddy" men. The four men all originally from Romania but then living in Coventry, were arrested on suspicion of theft and the van was seized. This highlights the opportunistic nature of the crime.

Case Study 8: In 2005, Police uncovered an illegal slaughterhouses on a farm near Harrogate, North Yorkshire which was being used to butcher sheep for the halal restaurant trade. Stephen Rossides, the director of the British Meat Processors Association, articulated that many of those living in rural communities had rudimentary knowledge of slaughtering and butchery. This case illustrates the illicit farm to restaurant trade. 
Case study $9^{16}$ - This case relates to three Asian farming brothers pleading guilty in 2009 to offences relating to the illegal slaughter of sheep and other associated charges. Animal Health Officers from Gloucestershire County Council Trading Standards Service visited the farm, on December 8 2008, during the festival of Eid, where they seized 59 sheep heads and 67 fleeces. They found that a poultry shed on the farm was being used to slaughter sheep for human consumption. Yusuf Jaffer's brothers aided and abetted in the enterprise. This case illustrates ethnic involvement in a wider supply chain case.

Case study $10^{17}$ - This case relates to two North Yorkshire farmers a father and son being caught for running an illegal slaughter house on their farm. They had hired a Muslim Halal Slaughterman. All three pled guilty and were jailed for short term sentences. The judge criticised the farmers for bringing farming into disrepute and for having a disregard for animal welfare. The slaughter site was insanitary with an open sewer running through it. The case came to light when animal welfare activists secretly filmed the illegal slaughters. Meat from the slaughterhouse was delivered to shops in Bradford and Keighley. The father and son admitted 11 offences of contravening the post-BSE protection regulations, failing to dispose properly of high-risk material and breaching rules on cattle movements, passports and records. They were found guilty of running an illegal slaughter house. They were banned from keeping cattle and sheep for 10 years. There was no indication of the source of the sheep illegally slaughtered.

The cases call into question the basic integrity of the farmers and industry insider involved and case study 6 in particular raises issues of ethics and supply chain integrity because the sheep were stolen to breed from. In the majority of cases the consumers have no way of knowing that they were purchasing meat which had been stolen or bred from stolen sheep. This 
is an important aspect of integrity in the food supply chain. From these cases a protean typology emerged (see table 1 below):-

\section{Insert table 1 here.}

A dichotomous construct emerges whereby we see the farmer as victim of crime and the farmer as willing participant in crime as an illegal diversification opportunity or as an illegal pluriactivity strategy. In developing this working typology it was considered necessary to restrict it to a UK mainland sample. ${ }^{18}$ Of the 20 accused, 13 of them can all be ascribed to the category of 'being of the land'. Sixteen were male. Ten of the males were over 40 and were farmers or farm workers. The current scale of the rustling in the UK points to the involve ment of organised crime gangs and the fact that the large numbers stolen are slaughtered for ready markets. The authorities blame unscrupulous restaurant bosses and backstreet market traders who sell chap cuts on a 'no-question' asked basis to punters for a fraction of high street prices. Yet the true picture is less prosaic. It is theft and illegal slaughter on an industrial level to service an existing supply chain. ${ }^{19}$

From an analysis of the stories online it is apparent that there is a suspicion that on many occasions the sheep rustlers probably knew the farmers targeted. The visible MO is to drive the sheep elsewhere and transport them direct to an abattoir or other site of illegal slaughter. Other types of farm theft can also cause financial distress to the farmers such as the loss of medicines, vaccinations and bloodlines. Moreover, the cost of replacing livestock and the vaccination of these new animals is a costly affair. Eaton (2010) reports on the new phenomenon of the 'traider', a cross between a raider and a trader. This is pertinent to the UK context of predatory farmers.

In relation to opportunity thesis the accused farmers had the knowledge, opportunity, motivation and motive to carry out the crime. They had the farming nouse, the insider 
knowledge and the necessary skills and rural social capital to carry out the thefts on an entrepreneurial scale. They have easy access to quad bikes, sheep dogs and transport to take the sheep quietly away from the locus of the theft. They have farm land or buildings to launder the stolen sheep and the knowledge and contacts in the slaughter industry. In addition, they have the networked contacts in ancillary rural industries to source the resources they require to facilitate the crime. The rogue and criminal farmers featured in this study also have a sound alibi for being in the countryside at any time of day whereas urban raiders do not. Under every day circumstance and by routine activities theories they blend into the idyll. Another theme to emerge from the cases is that the farmers were often caught because of a lack of forensic awareness and an ignorance of police procedures - e,g. failing to dispose of evidence such as identity tags etc or using their own cheque books to pay for supplies. Our research has led us to talk to a number of industry insiders who have privately confirmed this thesis (See Smith \& Laing, 2012). Urban thieves and organised criminals simply would not have such knowledge, nor the opportunity to conduct such thefts to such a professional standard. To farmers and farm workers the necessary skills are routine activities thus if the authorities are looking for suspects for sheep and livestock thefts then they will likely be connected to farming or the land in some way. This is helpful in building up a profile for investigators and legal representatives to use in deterring future crimes.

Another aspect of the typology relates to the differing modus operandi of the thieves. These range from organized to opportunist. Most sheep thefts are committed for resale to the meat trade although some farmers may steal for retention to bolster blood lines cheaply. Organized sheep thefts require insider industry knowledge and skills as well as trailers, quadbikes, and sheep dogs and sufficient manpower. The opportunist thefts merely require transport in the form of a van or car. Another form of theft entails shooting sheep in situ, butchering them and leaving the remains in the field. Obviously, inferences can be drawn from 
the crime scene which will assist investigators in establishing if it is amateur opportunists or industry insiders who are involved.

\section{Conclusions}

Livestock theft causes great financial distress to farmers and those located in semi-urban areas and near main roads are particularly vulnerable to such thefts (Donnermeyer \& Barclay, 2005). Nevertheless, there is a high levels of non-reporting (Donnermeyer, 2007). This is important because until we have an accurate assessment of the true scale of the problem then it will be difficult to legislate against and investigate the problem. It is not known whether the low rate of reporting emanates from an apathy on the behalf of the farmers or whether they have no faith in the authorities. Obviously, high value, high denomination livestock thefts hit the headlines but smaller scale theft may go unnoticed. This study is important because there are few texts on rural law enforcement and in particular sheep theft (Bristow, 1982). As a result of this study it is apparent that this is a supply chain issue worthy of a further detailed study from a supply chain context. If we know little about the organized, entrepreneurial nature of the illicit and illegal sides of the industry at the point of theft then we know even less about the wholesale and marketing side of the illegal supply chain and in particular how it interfaces with the legal supply chain. This article makes a start to documenting and theorising this phenomenon.

This study has illustrated that as argued by Wells (2003) livestock / sheep theft continues to change with the times and market conditions and with socio-economic and sociodemographic conditions and with changing work practices (i.e. many farmers no longer employ shepherds but tend the flocks themselves). However, sheep theft is no longer the petty crime 
described by Shakesheff and other historians. Howard (2004) made reference to the existence of rural rustling gangs and in this respect these still exist not out of necessity but for profit. We can learn lessons from history by examining the seasonal variations in sheep and livestock theft. Instead of relying on documentary evidence and on NFU reports we must access live police data on thefts across the entire UK and analyse crime patterns and MO's. There may be less seasonal fluctuation because of the insatiable demand for meat irrespective of its source but nevertheless a thorough analysis of the data would allow the typology identified herein to be populated with empirical evidence. An analysis of the data in real time would allow us to determine evidence of gang activity, levels of professionalism and recidivism (which are the levels of analysis used by Howard, 2004).

In relation to food supply chain integrity, the provenance of authenticating the resultant meat (Manning \& Smith, 2004) can be an important marketing tool (Sagoff, 1995) for the farmers, processors and suppliers of the food products. There is scope for contracts between the farmers and producers and the processors to make a declaration as to the source of the meat in the product which would allow for subsequent prosecution if the meat was found to be introduced illegally. The personal integrity of the people involved in the food supply chain should be of importance too (re Pritchard, 2006). Consumers should have a right of redress and a right to be protected from criminals in the food supply chain (Manning, Smith \& Soon, 2016) if they are knowingly sold falsely labelled or described food by unscrupulous farmers, producers and processors. Such predators should be banned from farming, not just from keeping animals.

There are obvious limitations in that, as yet, there are few detected rustling cases in the UK making the developed typology somewhat sketchy. However, a sketchy image is preferable to none at all. Another limitation is that much of the evidence upon which the typology is developed is anecdotal and will require verification by further empirical studies. 
Nevertheless, the typology should prove helpful to academics, supply chain theorists, insurance companies, investigators, industry insiders and farmers to help them understand this contemporary crime and how to prevent its spread. There is a need to learn the lessons from history and historians to help develop useful contemporary prevention and detection strategies. Also, as argued in the Foresight Report (2011) on the future of food and farming it will take an inter-disciplinary approach to combat food integrity and food crime issues. Nevertheless, the contemporary rustler is more of a free market entrepreneur than their historical counterpart. Livestock rustling is an opportunity driven organized criminal activity but it is not an opportunist crime. There is a need for a large scale survey of farmers in relation to insider driven criminal activity. Unlike the case with tractor theft (See Smith \& McElwee, 2015) there are no police special units targeting the crime. If this article sparks an interest in the subject and spawns further studies it will have served its purpose. ${ }^{20}$ Finally, there is a need for further research into the dark-side of the food supply chain including the role of abattoir owners in perpetuating food fraud.

\section{References}

Agnoli , L., Capitello , R., De Salvo „M., Longo , A., Boeri, M., (2016). Food fraud and consumers' choices in the wake of the horsemeat scandal". British Food Journal, 118 (8).

Alvarez, S. (2010). "Theories of Entrepreneurship: Alternative Assumptions and the Study of Entrepreneurial Action". Foundations and Trends in Entrepreneurship Vol. 1, No. 3

Andelt, W.F. (1992). "Effectiveness of livestock guarding dogs for reducing predation on domestic sheep". Wildlife Society Bulletin. 20 (1), pp. 55-62.

Arbnor, I., Bjerke, B. (1997). “Methodologyfor Creating Business Knowledge”, Thousand Oaks, CA: Sage Publications.

Ardichvili , A., Cardoza, R., \& Ray, S. (2003). "A theory of entrepreneurial opportunity identification and development". Journal of Business Venturing, 18(1), pp.105-123. 
Archer, 'J.E. (1999). "Poaching gangs and violence: the urban rural divide in nineteenthcentury Lancashire”. British J. Criminology 39, pp. 25-38,

Bristow, A.P. (1982). "Rural Law Enforcement". Needham Heights, MA. Allyn \& Bacon, Inc.

Bruley, S. (2010). "The Women and Men of 1926: A Gender and Social History of the General Strike", Self-Published.

Clack, W. (2014). What is livestock theft?: management The Dairy Mail, 21 (8), pp. 20-41.

Cohen, L.E., \& Felson, M. (1979). "“Social change and crime rate trends: a routine activity approach". American Sociological Review. 44, pp. 588-68.

Donnermeyer, J.F. (2007). "Rural crime: Roots and restoration". International Journal of Rural Crime, 1, pp.2-20.

Donnermeyer, J.F., \& Barclay, E. (2005). "The Policing of Farm Crime 1". Police Practice and Research, 6(1), pp. 3-17.

Dubin, R. (1978). “Theory Building”. Free Press, New York.

Eaton, D. (2010). The rise of the 'traider': the commercialization of raiding in Karamoja". Nomadic Peoples, 2, pp. 106-122.

Eckblom, P. (2009). Gearing Up Against Crime".

http://www.designagainstcrime.com/files/crimeframeworks/11_gearing_up_against_crime.pd $\underline{\mathrm{f}}$

Elliott Review into the Integrity and Assurance of Food Supply Networks - Final Report: A National Food Crime Prevention Framework, July 2014. HM Government. London.

Foresight. The Future of Food and Farming (2011). Final Project Report. The Government Office for Science, London.

Freeman, R.B., (1999). "The economics of crime". Handbook of Labor Economics. Vol 3, Part C., pp. 3529-3571.

Friedman, D., \& Sjostrom, W. (1992) "Hanged for a Sheep: The Economics of Marginal Deterrence". The Journal of Legal Studies, 22(2), pp. 345-366.

Gammelgaard, B. (2004) "Schools in logistics research?: A methodological framework for analysis of the discipline", International Journal of Physical Distribution \& Logistics Management, 34(6), pp.479 - 491,

Hobbsbawm, E. (2000). “Bandits”. The New Press.

Hofmeyr, I. (2014). "A Social Network that combats stock theft”. Stockfarm, 4(5), pp.8-9. 
Hofmeyr, I. (2015). "Bird's eye view to counting our herds: The leading edge technology". FarmBiz, (5(6), pp.50-51.

Hoorfar, J., Jordan, K., Butler, F., \& Prugger, R., (2011). Food chain integrity: A holistic approach to food traceability, safety, quality and authenticity. Oxford: Woodhead Publishing.

Howard, S. (2004). Investigating responses to theft in early and modern Wales: Communities, thieves and the courts". Continuity and Change, 19(3), pp 409-430.

Jones, J. (2010). "The neglected problem of farm crime: an exploratory study", Safer Communities, 9(1), pp. 36-44.

Jones, J. (2012), "Looking beyond the 'rural idyll': some recent trends in rural crime". Criminal Justice Matters, 89(1), pp. 8-9.

Kirzner, I.M. (1985). "Discovery and the capitalist process". Chicago: University of Chicago Press.

Lektzian, S., \& Perez, J. (2008). "Rustling: Ancient History or Current Event? Journal of Agricultural \& Food Information, 9(3). pp. 273-280.

Lever, J., McElwee, G., Smith, R., Papalexi, M. (2015) Illegal activity in the Halal Supply Chain. Working paper.

McKenzie, B. (2004). "Understanding Entrepreneurship: Towards a Grounded Theory" Frontiers of Entrepreneurship Research p.582.

Manning, L (2016: Forthcoming). Food fraud: policy and food chain.

Manning, L., \& Smith, R., (2015). Providing authentic (ated) food: An opportunity-driven framework for small food companies to engage consumers and protect the integrity of the food supply chain. The international journal of Entrepreneurship \& Innovation, 16 (2), pp. 97-110.

Manning, L., \& Soon, J. M., (2014). Developing systems to control food adulteration. Food Policy, 49 (1), pp. 23-32.

Mears, D.P. Scott, M.L., Bhati, A.S. (2007).”Opportunity Theory and Agricultural Crime Victimization". Rural sociology, 72(2), pp. 151-184.

Platt, S. (2015). “Criminal Capital”. Basingstoke: Palgrave MacMillan. 
Pritchard, M. S., (2006). Professional integrity: Thinking ethically. Kansas: University Press of Kansas.

Richey, D. (1977). Precinct System - A Preventative Action against Rural Theft and Cattle Rustling”. Police Chief, 44 (6), pp 40-41.

Robson, C. (2013). “Real World Research”. London: John Wiley \& Sons.

Rule J. G. (ed.), (1982). “Outside the law. Studies in crime and order, 1650-1850”. Exeter Papers in Economic History, University of Exeter Press.

Sagoff, M., (1995). The Value of Integrity. In Westra, L \& Lemons, J. Perspectives on Ecological Integrity, Volume 5 of the series Environmental Science and Technology Library pp 162-176.

Scott, J. (2006). "Documentary Research". London, Sage Publications Ltd.

Scott, J. (2014). “A Matter of Record: Documentary Sources in Social Research”. London: John Wiley.

Scott, C., Lundgren, H., \& Thompson, P. (2011). "Guide to Supply Chain Management". Berlin: Springer.

Shakessheff. T. (2003) "Rural Conflict, Crime and Protest: Herefordshire, 1800-1860”, Martlesham, Suffolk: Boydell Press.

Shane, S \& Venkataraman. S. (200). "The promise of entrepreneurship as a field of research". Academy of management review, 25 (1), pp. 217-226.

Shears, P. (2010). "Food Fraud - a current issue but an old problem". British Food Journal, $112(2)$.

Smith, R. (2004) "Rural rogues: a case story on the "smokies" trade", International Journal of Entrepreneurial Behaviour \& Research, 10(4). pp.277 - 294.

Smith, R. (2010). "Policing the changing landscape of rural crime: a case study from Scotland". International Journal of Police Science \& Management, 12(3), pp. 373-387.

Smith, R., McElwee, G. (2013). 'Confronting Social Constructions of Rural Criminality: A case story on 'Illegal Pluriactivity' in the Farming Community'. Sociologia Ruralis. 53 (1), pp. 112-134. 
Smith, R., Laing, A., McElwee, G., (2012). "Organized Rural Crime Groups”, RUSource www.nationalrural.org/organisation http:/hdl.handle.net/10059/803

Smith, R., Laing, A., McElwee, G., (2013). "The rise of illic it rural enterprise within the farming industry: A viewpoint". International Journal of Agricultural Management, 2(4), 185-188.

Wells, R.A.E (1984). "Sheep-rustling in Yorkshire in the age of the industrial and agricultural revolutions". Northern History, 20(1), pp. 127-145.

Woodward, N. (2008)/ "Seasonality and sheep-stealing: Wales, 1730-1830. Agricultural History Review, 56(I), pp. 25-47.

\section{Figures and Tables}

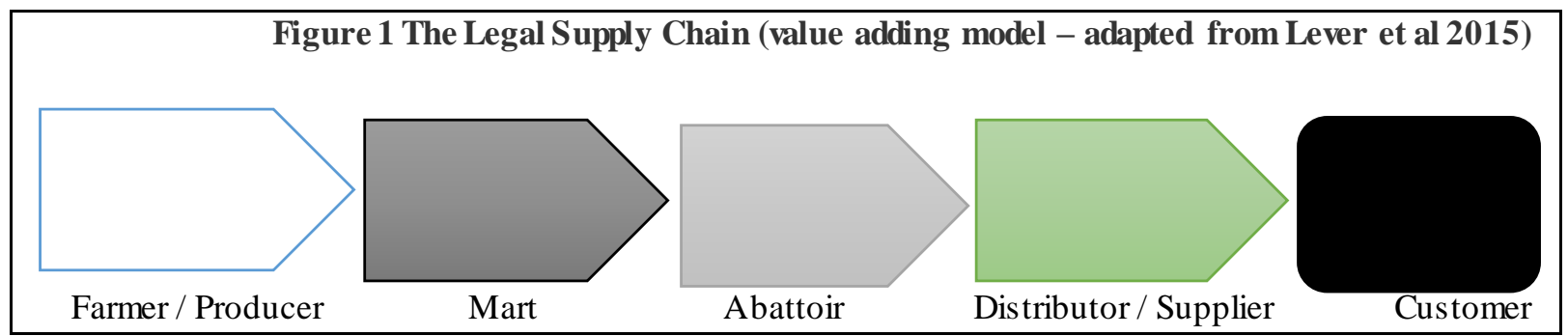

Figure 2 The Illegal Supply Chain (value extracting model - (adapted from Lever et al, 2015)

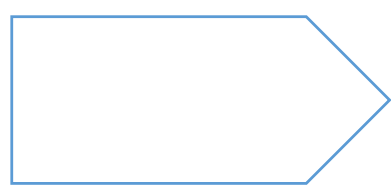

Farmer/ Producer

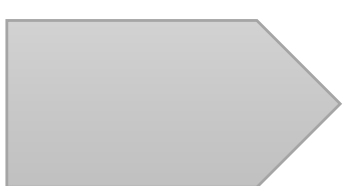

Abattoir

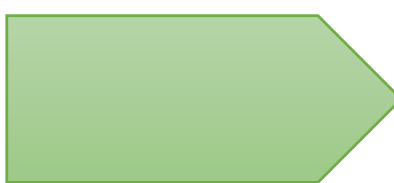

Distributor / Supplier

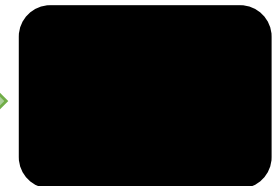

Customer

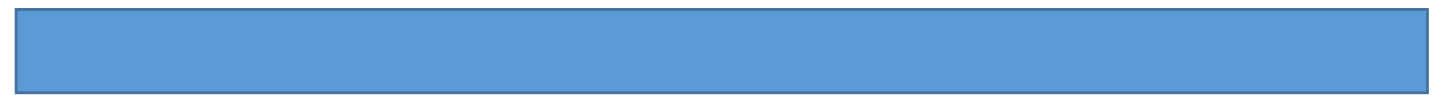

Thieves

\begin{tabular}{|l|l|l|}
\hline \multicolumn{1}{|c|}{$\begin{array}{c}\text { Typological } \\
\text { Category }\end{array}$} & \multicolumn{1}{c|}{ Description } & \multicolumn{1}{c|}{ Opportunity Fit } \\
\hline Of the land & $\begin{array}{l}\text { This category of offenders have an obvious } \\
\text { and direct connection to the land and to }\end{array}$ & $\begin{array}{l}\text { The farmer has the strongest fit in relation to } \\
\text { routine activities theory and opportunities }\end{array}$ \\
\hline
\end{tabular}




\begin{tabular}{|c|c|c|}
\hline $\begin{array}{l}\text { Farmer } \\
\text { Farm Manager } \\
\text { Agricultural } \\
\text { Contractor } \\
\text { Farm Worker } \\
\text { Rural Resident }\end{array}$ & $\begin{array}{l}\text { farming. The farmer is usually above } \\
\text { suspicion as is the farm manager. The farm } \\
\text { worker may fit the stereotype of the criminal, } \\
\text { particularly if they have a criminal record. } \\
\text { Also, long-term residents in rural areas may } \\
\text { have picked up knowledge and skills } \\
\text { necessary for the theft of livestock. }\end{array}$ & $\begin{array}{l}\text { thesis because they either own or rent the } \\
\text { farm. They have autonomy of decision } \\
\text { making and can exercise a degree of control } \\
\text { over official record-keeping activity. The } \\
\text { farmer has the knowledge, skill and contacts } \\
\text { necessary. They have access to the resources } \\
\text { required to successfully steal and launder } \\
\text { stolen animals. The farm manager, unless } \\
\text { they have a similar autonomy of decision } \\
\text { making, is a less likely suspect. In some case } \\
\text { farm managers act at a level similar to the } \\
\text { autonomous farmer where the farmer is an } \\
\text { absentee landlord. Farmers and farm } \\
\text { managers usually have a lengthy period of } \\
\text { tenure on their farms whereas many farm } \\
\text { workers are transitory and may work on many } \\
\text { farms in an area. Agricultural contractors and } \\
\text { their employees have almost unlimited access } \\
\text { to farms due to the nature of their jobs. Rural } \\
\text { residents may also have had short-term or } \\
\text { seasonal stints on farms and may have } \\
\text { sufficient knowledge of rural ways to facilitate } \\
\text { such crime. The main point to take away from } \\
\text { this category is that they will likely be the last } \\
\text { people police suspect. }\end{array}$ \\
\hline $\begin{array}{l}\text { Criminal Labour } \\
\text { Rural Dw ellers } \\
\text { Urban Dwellers } \\
\text { Travellers }\end{array}$ & $\begin{array}{l}\text { This category is self-explanatory but } \\
\text { nevertheless requires articulation. Rogue and } \\
\text { criminal farmers and the criminal } \\
\text { animateur/entrepreneur who organises project } \\
\text { based entrepreneurial crimes, will often need } \\
\text { labour for committing the thefts or } \\
\text { participating in illegal slaughters. There are } \\
\text { two obvious sources - ruraldwellers and urban } \\
\text { dwellers. Two other, less visible forms of } \\
\text { criminal labour are travellers and migrant } \\
\text { workers. }\end{array}$ & $\begin{array}{l}\text { Many people who live in the country have } \\
\text { some knowledge and experience of farming, } \\
\text { or associated practices. Ruraldwellers may be } \\
\text { willing to participate in undeclared work. } \\
\text { They may also be involved in other illicit rural } \\
\text { netw orks such as poaching or illegal dog } \\
\text { breeding etc. They can also be a source of } \\
\text { intelligence to be exploited by criminals. The } \\
\text { urban dweller, used as a source of criminal } \\
\text { labour, may or may not have experience of } \\
\text { farming or the land and will most likely be } \\
\text { known to the authorities for acquisitive or } \\
\text { drug related crime. They have less of an alibi } \\
\text { for being in the countryside than rural } \\
\text { dwellers. Travellers by the very nature of } \\
\text { their itinerant lifestyle, will have worked in } \\
\text { many occupations, including rural } \\
\text { occupations such as farming. They may have } \\
\text { skills associated with poaching and will have } \\
\text { a working knowledge of dogs. Whilst there is } \\
\text { no current intelligence or documented } \\
\text { evidence to suggest that travellers are } \\
\text { involved in livestock theft at present, their } \\
\text { participation cannot be ruled out. They have } \\
\text { the opportunity and presence and are not seen } \\
\text { as being out of place in the countryside. There } \\
\text { are reports of small numbers of sheep being } \\
\text { slaughtered in the countryside and the remains } \\
\text { being left in fields (mirroring the practice }\end{array}$ \\
\hline
\end{tabular}




\begin{tabular}{|c|c|c|}
\hline & & $\begin{array}{l}\text { reported in historical studies). This is } \\
\text { certainly worthy of further study. The final } \\
\text { type is the migrant worker with both } \\
\text { knowledge and opportunity. From reading } \\
\text { relating to the Irish context there is evidence } \\
\text { that migrant workers stealsheep to fatten them } \\
\text { in gardens before slaughtering them for the } \\
\text { purposes of feeding their families. }\end{array}$ \\
\hline $\begin{array}{l}\text { Meat Industry } \\
\text { Insiders } \\
\text { Abattoir Owner } \\
\text { Butchers } \\
\text { Slaughter } \\
\text { men/Freelancers }\end{array}$ & $\begin{array}{l}\text { These individuals may have no obvious } \\
\text { connection to farming but, as they are } \\
\text { involved in the downstream production } \\
\text { activity, they will also have knowledge of } \\
\text { working with animals. }{ }^{21} \text { Abattoir owners, } \\
\text { being entrepreneurs, will likely be above } \\
\text { suspicion. Conversely, butchers, although } \\
\text { usually held in high esteem, have traditionally } \\
\text { been suspected involvement in illegal } \\
\text { slaughter and sharp business practices } \\
\text { normally dealt with by Trading Standards. } \\
\text { The Slaughterman is a trained professional } \\
\text { with experience of handling animals. }\end{array}$ & $\begin{array}{l}\text { Many abattoir owners may also be "of the } \\
\text { land" and indeed, many are farmers and run } \\
\text { duel businesses simultaneously. In this } \\
\text { respect they have the opportunity and motive } \\
\text { to become involved in illegal dealing. Apart } \\
\text { from a registration number on an ear tag there } \\
\text { is very little to differentiate between } \\
\text { legitimate and stolen sheep in an abattoir. The } \\
\text { recent spate of prosecutions relating to the } \\
\text { horsemeat scandal bear testament to this. } \\
\text { There is very little known in contemporary } \\
\text { terms about the involvement of butchers in the } \\
\text { illegal trade and much of that is anecdotal } \\
\text { Likewise, we know little about the } \\
\text { slaughtermen acting as freelance agents. }\end{array}$ \\
\hline $\begin{array}{l}\text { Associated Small } \\
\text { Business Owners } \\
\text { Agricultural } \\
\text { Contractors } \\
\text { Hauliers }\end{array}$ & $\begin{array}{l}\text { These individuals (synonymous with } \\
\text { Howard's Artisans) may be involved in } \\
\text { livestock theft because they have access to } \\
\text { JCBs, Lorries and other equipment required } \\
\text { for the transportation of stolen animals or the } \\
\text { disposal of the resultant offal and waste. }\end{array}$ & $\begin{array}{l}\text { Although many farmers have small trailers } \\
\text { and Lorries they may not have the capacity to } \\
\text { transport large numbers of stolen livestock in } \\
\text { one journey. This may necessitate sub- } \\
\text { contracting the transport activity. As most } \\
\text { livestock theft appears to occur overnight, it is } \\
\text { difficult to believe that a legitimate haulier } \\
\text { would be unaw are of the clandestine nature of } \\
\text { the activity. Likewise, a legitimate } \\
\text { agricultural contractor would know the } \\
\text { difference between legal and illegal contracts. } \\
\text { However, as off-the-books and informal } \\
\text { enterprise are embedded in ruralw orking class } \\
\text { culture, it is possible that such individuals may } \\
\text { engage in moonlighting to supplement their } \\
\text { income. It is unlikely that any such individual } \\
\text { would be innocent unless the theft occurred } \\
\text { during daylight hours. See Smith \& McElwee } \\
\text { (2015) for details of how tractor thieves dupe } \\
\text { hauliers into unknowingly transporting stolen } \\
\text { property. }\end{array}$ \\
\hline $\begin{array}{l}\text { Urban Marauders } \\
\text { Organized Crime } \\
\text { Groups versus } \\
\text { Opportunists }^{22}\end{array}$ & $\begin{array}{l}\text { This category of urban criminal cannot be } \\
\text { discounted. Urban marauders are involved in } \\
\text { the organised theft of tractors and other } \\
\text { equipment from farms. The category of } \\
\text { opportunists is still relevant as there are } \\
\text { reports of small scale thefts of livestock which } \\
\text { could be the work of such individuals. }{ }^{23}\end{array}$ & $\begin{array}{l}\text { Of the typology, the urban thief is the least } \\
\text { likely suspect in such cases. The involvement } \\
\text { of settled urban criminals, who have relocated } \\
\text { from urban areas to live in isolated rural } \\
\text { cottages, cannot be overlooked. The settled } \\
\text { urban criminal will most likely gravitate } \\
\text { towards friendships with indigenous rural } \\
\text { rogues. Although it is not currently believed } \\
\text { that they possess the knowledge and skills }\end{array}$ \\
\hline
\end{tabular}




\begin{tabular}{|l|l|l|}
\hline & $\begin{array}{l}\text { necessary to facilitate livestock theft, it is not } \\
\text { beyond the realms of possibility that they } \\
\text { could sub-contract the theft to organised crime } \\
\text { groups with a knowledge of farming ways. } 24\end{array}$ \\
\hline
\end{tabular}

Table 1 - A Protean Typology of Livestock Thieves from a Supply Chain Perspective End Notes

\footnotetext{
${ }^{1}$ However, there is evidence that during the General Strike of 1926 and the Miner's Strike of 1984 strikers supplemented their loss of income by poaching game and by stealing sheep to feed their families. This was condoned by some farmers as being socially acceptable banditry. See Bruley (2010) and the website http://www.countryfile.com/countryfile-tv/adam-hensons-farm-talk-sheep-rustling for fuller details.

${ }^{2}$ See the online news article - http://www.professionalsecurity.co.uk/blogs/jim-gannons-blog/october-2014 countryside-crime/

${ }^{3}$ This is an important facet of the argument in that traditionally in Britain rural crime and roguery have notbeen taken seriously. In the UK 19990's television series Heartbeat the hapless rural rogue was always poaching or stealing sheep from unsuspecting fellow farmers. Yet, he was portrayed as a bumbling likeable rogue. There is still a lingering sense of this social typecasting remaining in the farming community who still believe that rural crime is committed by predatory urban marauders.

${ }^{4}$ It must be stressed that there is a burgeoning literature on rustling in an African or developing countries context. In this article we do not take cognisance of this context because it is based primarily on cultural and often tribal behaviours and practices as well as policing practices which have little meaning in a Western context. It is not the purpose of this article to review these, nor to even document them.

${ }_{5}^{5}$ http://www.theguardian.com/environment/2014/sep/26/raiders-of-night-farmers-livestock-thieves-rustling

${ }^{6}$ UNDERWORLD crime gangs are targeting Scotland's farms in a rural crime explosion http://www.dailyrecord.co.uk/news/s cottish-news/underworld-gangs-behind-explosion-in-livestock$\underline{1166893}$
}

${ }^{7}$ http://www.countryfile.com/countryfile-tv/adam-hensons-farm-talk-sheep-rustling

${ }^{8}$ See http://www.nfuonline.com/science-environment/rural-concerns/rural-crime-on-the-national-agendal and http://www.independent.co.uk/news/uk/crime/sheep-rustling-fleecing-the-countryside-9016618.html

9 http://www.dailymail.co.uk/news/article-2193139/Sheep-rustlers-convicted-25-years-stealing-pregnantewes.html

10 SHEEP STEALING CONVICTION IS 'VICTORY FOR CUMBRIAN FARMERS' http://www.newsandstar.co.uk/news/sheep-stealing-conviction-is-victory-for-cumbrian-farmers-1.1102973

${ }^{11}$ Jail forGisbum man who stole sheep-http://www.clitheroead vertiser.co.uk/news/crime/jail-for-gis burn-man-who$\underline{\text { stole-sheep-1-7117364 }}$

${ }^{12}$ SHEEP farmers have reacted with dis may after an alleged rustling case was dropped — and fear it may lead to more theft $=\underline{\mathrm{http}} / / /$ www.southwales-eveningpost.co.uk/Farmer-fears-alleged-sheep-rustling-case-dropped/story22961292-detail/story.html

${ }^{13}$ A prominent Dales farmer and former judge at the Great Yorks hire Show has been cleared of sheep rustling after a criminal trial - http://www.harrogateadvertiser.co.uk/news/crime/dales-farmer-cleared-of-theft-in-sheeprustling-trial-1-6619975

${ }^{14}$ Five members of farming family in court over use of sheep allegedly stolen from 14 other farms http://www.thenorthemecho.co.uk/news/11530856. Five members of farming family in court over use of sh eep allegedly stolen from 14 other farms 
15 Police uncovered sheep rustlers after stopping van with broken headlighthttp://www.northamptonchron.co.uk/news/crime/police-uncovered-sheep-rustlers-after-stopping-vanwith-broken-headlight-1-5916598

${ }^{16}$ Brothers in court over illegal meat s laughter - http://www.gloucestercitizen.co.uk/Brothers-court-illegalmeat-slaughter/story-11853637-detail/story.html

${ }^{17} \mathrm{http}: / /$ news.bbc.co.uk/1/hi/england/north yorkshire/4420701.stm

${ }^{18}$ This is because of the different demographic and socio-political features of the Irish situation. In Ireland, the picture is somewhat skewed by the active presence of gangs associated with paramilitary organisations and with cros s border criminality. Moreover, the Iris h records do not as a general rule provide details of the occu pations of the thieves and this would require further field research to verify the facts.

${ }^{19} \mathrm{http}: / /$ www.express.co.uk/news/uk/370423/We-re-catching-sheep-rustlers-on-the-hoof.

\footnotetext{
${ }^{21}$ See http://smallbusiness.chron.com/definitions-upstream-downstream-production-process-30971.html for an explanation of the terminologies of upstreamand downstreamin supply chain theory. In general terms livestock farming in this respect is regarded as being upstream and the abattoir sector being downstream

${ }^{22} \mathrm{http} / / / w w w . d a i l y$ mail.co.uk/news/article-2328919/Cruel-friends-killed-s heep-hammer-butchered-field-freeroast-dinner.html

${ }^{23} \mathrm{See}$ http://www.thepressnews.co.uk/press-news/shock-anger-sheep-slaughter/ and

http://www.fwi.co.uk/livestock/warning-after-thieves-butcher-sheep-in-field.htm
} 